1. Bоск, A.-Beschreibung eines atypischen Zyklops. Klin. Monatsbl. f. Augenheilk., 1889.

2. MEEKER, L. H. and AEBLI, R.-Cyclopean eye and lateral proboscis with normal one-half face. Arch. of Ophthal., Vol. XXXVIII, p. 159, August, 1947.

3. SCHIECK, F. and BrÜCKNer, A.-Kurzes Handbuch d. Ophthal., Bd. 1, 1930.

4. Seefelder, R.-Missbildungen des menschlichen Auges. Auges.. S. 519-630.

\title{
ANNOTATION
}

\section{"What's in a Name?"}

The question is one which has often been asked, and in medicine one might be tempted to reply- "a good deal more than was ever meant to be in it, and sometimes the exact opposite." The classical

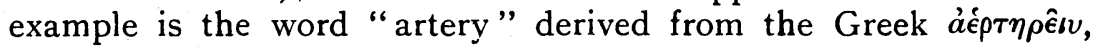
meaning to hold air, and so called because the tubes the words designate were thought to carry air from the heart or trachea, as Trevisa wrote in 1398 " to bere and brynge kindily heete from the herte to all the membres." Any attempt to change artery to a word meaning "carry blood" would, however, rouse strenuous opposition, and could only result in a much less elegant one.

Several examples are to be found in our own branch of medicine, the best known being cataract and glaucoma. "Cataract" has been attributed by some to the ancient theory that it was caused by a fall of inspissated material into the pupil, but others derive it from the second meaning which was " portcullis." This is more rational, because as the portcullis obstructs vision in a gateway, so does the cataract obstruct vision in the eye.

Glaucoma is a useful word, because being meaningless-literally translated, it signifies a gray-green tumour-it serves to cover our uncertainty as to the pathology of the disease.

Hypermetropia and myopia might come in for criticism, since the former means an eye beyond measure-a curious phrase to apply to an eyeball whose usual defect is that it is too small and the latter a closed, and therefore by inference a small eye, but it is doubtful whether micropia and megalopia would ever be accepted as respectively synonymous, even though they described the condition more accurately.

That a knowledge of Classics is not always a help to medical students was demonstrated in an examination held a few years ago at a certain hospital. ' One of the questions consisted in asking the meaning of various ophthalmological terms, among which were epiphora and hyperphoria. Epiphora was correctly defined by a candidate as an overflow of tears, but hyperphoria was beyond him, so he summoned his knowledge of Greek to his aid, and stated that hyperphoria meant a really good cry. 